\title{
New insights into the pathogenesis and prevention of \\ tuberous sclerosis-associated neuropsychiatric disorders
}

\section{(TAND) [version 1; peer review: 3 approved]}

\author{
Tanjala T. Gipson1, Michael V. Johnston (iD)2 \\ ${ }^{1}$ Boling Center for Developmental Disabilities, LeBonheur Children's Hospital, University of Tennessee Health Sciences Center, \\ Memphis, TN, USA \\ ${ }^{2}$ Kennedy Krieger Institute, Johns Hopkins University School of Medicine, Baltimore, MD, USA
}

V1 First published: 09 Jun 2017, 6(F1000 Faculty Rev):859
https://doi.org/10.12688/f1000research.11110.1

Latest published: 09 Jun 2017, 6(F1000 Faculty Rev):859

https://doi.org/10.12688/f1000research.11110.1
Open Peer Review

Approval Status

1

2

3

version 1

09 Jun 2017

Faculty Reviews are review articles written by the prestigious Members of Faculty Opinions. The articles are commissioned and peer reviewed before publication to ensure that the final, published version is comprehensive and accessible. The reviewers who approved the final version are listed with their names and affiliations.

\footnotetext{
1. Paolo Curatolo, Tor Vergata University of Rome, Rome, Italy

2. Peter Crino, University of Maryland School of Medicine, Baltimore, USA

3. Mustafa Sahin, Boston Children's Hospital, Harvard Medical School, Boston, USA Any comments on the article can be found at the end of the article.
} 
Corresponding author: Tanjala T. Gipson (bcddndd@uthsc.edu)

Competing interests: The authors declare that they have no competing interests.

Grant information: The author(s) declared that no grants were involved in supporting this work.

Copyright: @ 2017 Gipson TT and Johnston MV. This is an open access article distributed under the terms of the Creative Commons Attribution License, which permits unrestricted use, distribution, and reproduction in any medium, provided the original work is properly cited.

How to cite this article: Gipson TT and Johnston MV. New insights into the pathogenesis and prevention of tuberous sclerosisassociated neuropsychiatric disorders (TAND) [version 1; peer review: 3 approved] F1000Research 2017, 6(F1000 Faculty Rev):859 https://doi.org/10.12688/f1000research.11110.1

First published: 09 Jun 2017, 6(F1000 Faculty Rev):859 https://doi.org/10.12688/f1000research.11110.1 
Tuberous sclerosis complex (TSC) affects 1 out of 6,000 live births and is the second most common neurocutaneous disease (neurofibromatosis is the most common) ${ }^{1}$. The skin manifestations of TSC, including facial angiofibromas, periungual fibromas, hypomelanotic macules formerly known as "ash leaf spots", and areas of thickened leathery skin (shagreen patches), were recognized clinically long before the pathogenesis was identified. TSC causes multi-system involvement, including benign tumors in the brain, kidneys, heart, eyes, lungs, and skin as well as seizures, intellectual disability, autism spectrum disorders, and other neuropsychiatric disorders. It is inherited in an autosomal dominant pattern, but the rate of spontaneous mutations is high ${ }^{1}$. The neurobiology of TSC has been linked to mutations in the TSC1 or TSC2 genes leading to dysfunction of the TSC1 or TSC2 proteins, which form a complex that usually inhibits mechanistic target of rapamycin (mTOR) $)^{2,3}$. These proteins form a complex that integrates the input from upstream cellular pathways, including insulin, growth factors (such as insulin-like growth factor1 and brain-derived neurotrophic factor), and amino acids. The mTOR pathway is a central regulator of mammalian metabolism and physiology and normally senses cellular nutrient, oxygen, and energy levels ${ }^{4}$. Dis-inhibition of this pathway caused by loss-of-function mutations in TSC1 or TSC2 leads to generally benign overgrowth or tumors in brain, kidney, skin, eye, and other organs that are the clinical hallmarks of the disorder ${ }^{3}$. In addition to TSC, alterations in MTOR have been reported in a number of other genetic neurologic disorders, including neurofibromatosis 1 , fragile X syndrome, Proteus syndrome, and phosphatase and tensin homolog (PTEN) mutations in Cowden syndrome, LhermitteDuclos syndrome, and related disorders ${ }^{3}$. PTEN mutation disorders are usually associated with macrocephaly and may be associated with cancer.

A specific combination of major and minor features of TSC is required to make a clinical diagnosis of the disorder (Table 1$)^{5}$. An identified genetic mutation in either TSC1 or TSC2 is also an independent criterion for diagnosis. Epilepsy $(90 \%)^{6-13}$, intellectual disability $(45 \%)^{14-18}$, and autism $(61 \%)^{19-33}$ are prominent features of TSC but are relatively non-specific and are not diagnostic. Autism, intellectual disability, and related conditions are classified as TSC-associated neuropsychiatric disorders (TAND) ${ }^{34}$.

Two drugs that inhibit mTOR, sirolimus and everolimus, which were originally developed as immunosuppressive and anticancer agents, have recently been applied to treat the manifestations of TSC. These drugs are now US Food and Drug Administration (FDA)-approved for TSC-associated subependymal giant cell astrocytomas (SEGAs), renal angiomyolipomata, and pulmonary lymphangioleiomyomatosis ${ }^{35-38}$. Deficiency of the major inhibitory neurotransmitter amino acid GABA (gamma-aminobutyric acid) has been linked to the high incidence of seizures in $\mathrm{TSC}^{39,40}$, and the anticonvulsant drug vigabatrin, an irreversible inhibitor of GABA transaminase, which degrades GABA, has been shown to be effective for treatment of infantile spasms and refractory complex partial seizures associated with $\mathrm{TSC}^{41,42}$. European practice guidelines recommend it as a first line for treatment of seizures in infants with $\mathrm{TSC}^{43}$, and it is considered as neurobiologically targeted treatment for TSC.

\section{Treatment of seizures in patients with tuberous sclerosis complex}

Several recent studies have reported beneficial effects of everolimus for epilepsy in patients with TSC. Krueger et al..$^{44}$ studied the effect of everolimus in children older than 2 years of age with confirmed TSC and medically refractory epilepsy averaging two or more seizures a week in the months prior to enrollment. These patients failed to respond to trials of two other anticonvulsants. Fourteen of 18 patients who completed the study over 48 months were reported to have a $48 \%$ reduction in seizures with few side effects. Samueli et $a l .{ }^{45}$ reported on the effect of everolimus in 15 children with TSC less than 18 years of age who had focal seizures, tonic clonicseizures, or drop attacks (or a combination of these); the authors found that $80 \%$ of patients reported fewer seizures and that $58 \%$ were seizure-free at a median follow-up of 22 months. French et al. ${ }^{46}$ reported on a placebo controlled trial of 366 patients (age range of 2 to 65 years) who were given everolimus as an add-on therapy for treatment-resistant focal onset seizures associated with TSC (EXIST-3); the authors found response rates of $29 \%$ in patients given a low dose, $40 \%$ in patients given a higher dose, and $15 \%$ in a placebo control group. Adverse drug reactions led to discontinuation of medication in $2 \%$. These trials indicate that mTOR inhibition shows promise for improving seizure control in patients with TSC.

\section{Spectrum of tuberous sclerosis complex-associated neuropsychiatric disorders}

TAND is a term that encompasses the multi-faceted nature of neurodevelopmental disabilities seen in patients with TSC, including behavioral, psychiatric, intellectual, academic, neuropsychological,

Table 1. Major and minor features required to make a clinical diagnosis of tuberous sclerosis complex.

\begin{tabular}{|c|c|}
\hline Major features & Minor features \\
\hline $\begin{array}{l}\text { 1. Hypomelanotic macules } \\
\text { ( } \geq 3 \text { at least } 5 \mathrm{~mm} \text { in diameter) }\end{array}$ & 1. "Confetti" skin lesions \\
\hline $\begin{array}{l}\text { 2. Angiofibromas }(\geq 3) \text { or fibrous } \\
\text { cephalic plaque }\end{array}$ & 2. Dental enamel pits (>3) \\
\hline 3. Ungual fibromas ( $\geq 2$ ) & 3. Intraoral fibromas ( $\geq 2)$ \\
\hline 4. Shagreen patch & 4. Retinal achromatic patch \\
\hline 5. Multiple retinal hamartomas & 5. Multiple renal cysts \\
\hline 6. Cortical dysplasias ${ }^{a}$ & 6. Nonrenal hamartomas \\
\hline 7. Subependymal nodules & \\
\hline $\begin{array}{l}\text { 8. Subependymal giant cell } \\
\text { astrocytoma }\end{array}$ & \\
\hline 9. Cardiac rhabdomyoma & \\
\hline 10. Lymphangioleiomyomatosis ${ }^{b}$ & \\
\hline 11. Angiomyolipomas (>2) ${ }^{b}$ & \\
\hline
\end{tabular}

aDefinite diagnosis: Two major features or one major feature with at least two minor features. Possible diagnosis: Either one major feature or at least two minor features. Cortical dysplasia includes tubers and cerebral white matter radial migration lines. ${ }^{b} \mathrm{~A}$ combination of the two major clinical features (lymphangioleiomyomatosis and angiomyolipomas) without other features does not meet criteria for a definite diagnosis. 
and psychosocial difficulties ${ }^{47-49}$. Behavioral manifestations may be relatively mild such as poor eye contact or more severe disorders on the autism spectrum, including self-injury (10\%) and aggression $(45 \%)^{49-51}$. Anxiety, depression, attention-deficit/hyperactivity disorder, autism spectrum disorder, and other psychiatric concerns are also common among patients with $\mathrm{TSC}^{13,52-55}$. It is estimated that as many as $50 \%$ may be impacted by some level of intellectual disability ${ }^{13,52-56}$. Academic difficulties in the absence of intellectual disability have also been observed in $30 \%$ of individuals with $\mathrm{TSC}^{56}$. Specific neuropsychological deficits, such as impaired working memory, may also be problematic ${ }^{55}$. The concept of TAND also encompasses the psychosocial impact of the individual's condition on the rest of the family ${ }^{57}$. To enable physicians and other medical professionals to screen for these concerns, the TAND checklist has been created $^{34}$.

\section{Treatment of tuberous sclerosis-associated neuropsychiatric disorder}

There are no medications approved by the FDA for treatment of TAND, and more progress is needed in this area. Several studies of genetic mouse models of TSC suggest that mTOR inhibitors can reverse deficits in synaptic plasticity, neurobehavior, social impairment, and repetitive behaviors ${ }^{3}$. In an open-label phase II trial to evaluate the efficacy and safety of rapamycin in adults with angiomyolipomata and TSC, seven out of eight patients had improvement in neurocognitive deficits, including list learning and story recall ${ }^{58}$. Two studies are in progress to address the treatment of TAND ${ }^{46}$. The RAD001 Neurocognition Trial (www.ClinicalTrials.gov/ct2/ show/NCT01289912) is a phase II randomized trial of everolimus in children and young adults ages 6 to 21 years who are being followed with neuropsychological testing. The phase III EXIST-3 trial (NCT01713946) is evaluating the effects of everolimus by using the Vineland Adaptive Behavior Scales, Second Edition ${ }^{59}$. In a young man with TSC, a SEGA, epilepsy, aggression, and self-injurious behavior, treatment with everolimus resulted in size reduction of his SEGA, reduction in self-injurious behavior, and diminished seizure frequency ${ }^{60}$. Discovering the potential role for neurobiologically targeted medications for behavior in TSC is the basis of our ongoing research program.

\section{Early treatment of infantile spasms may salvage cognitive development}

The inter-relationship between infantile spasms and TAND in tuberous sclerosis is an interesting one that may hold clues to the pathways by which TSC can cause autism and intellectual disabilities. Approximately $30 \%$ of patients with TSC present in infancy with infantile spasms, a severe form of epilepsy associated with a hypsarrhthymia pattern on electroencephalography. These patients are at much greater risk for severe autism, intellectual disability, and behavioral disorders compared with TSC patients who do not have infantile spasms. On the other hand, patients with idiopathic infantile spasms are at much lower risk for TAND than are patients with TSC. Early treatment with vigabatrin appears to be protective against severe TAND. For example, one study of infants with TSC compared (a) initiation of treatment with vigabatrin at the onset of electroencephalogram (EEG) abnormalities on anticipatory recordings determined before seizures were witnessed with (b) treatment initiation upon the onset of witnessed seizures ${ }^{61}$. No cases of severe/profound intellectual disability were detected among those with the EEG-based treatment ${ }^{61,62}$. A second study, designed to address the question of whether an EEG could be used as a biomarker in infants with TSC, validated its use in this regard ${ }^{63}$. Bolton et al. ${ }^{16}$ reported that TSC2 mutations were also associated with significantly higher cortical tuber count than TSC1 mutations, and the tuber count was directly related to earlier age and onset of seizures. In turn, the severity of epilepsy was strongly associated with the degree of intellectual impairment. Structural equation modeling, a multivariate statistical analysis technique that combines factor and multiple regression analysis to analyze structural relationships, supported a causal pathway from genetic abnormality to tuber count to epilepsy, including infantile spasms, to severity of intellectual outcome ${ }^{64}$. Humphrey et al. reported that there is a dosedependent impairment of intellectual development following exposure to infantile spasms in children with $\mathrm{TSC}^{64}$. Recently, it was reported that hormonal therapy with either adrenocorticotropic hormone or prednisolone plus vigabatrin is significantly more effective than hormonal therapy alone at stopping infantile spasms in infants without $\mathrm{TSC}^{65,66}$. Therefore, evaluating combination therapy could be useful in patients with TSC and spasms as early termination of spasms is critically important to prevent additional injury.

\section{Summary}

Tuberous sclerosis is a genetic multi-system disease that can have a major impact on the developing brain to cause seizures and an array of severe neuropsychiatric disorders, including severe intellectual disability and autism spectrum disorders. Recognition of the role of mutations in the TSC1 and TSC2 genes and the mTOR signaling pathways has led to the use of mTOR inhibitors to arrest or lessen the impact of the disorder. These medications have had a major impact in the brain and may also have an anti-epileptic effect. The concept of TAND has led to greater recognition of a host of disorders that can cause a great deal of impairment. The development of a common terminology for TAND to address the varying levels of involvement and the creation of the TAND checklist to aid clinicians and researchers in screening for these concerns provide a foundation for uniformity. Recognition that early onset of seizures, especially infantile spasms, are common in infants with TSC and that early onset of infantile spasms and associated hypsarrhythmia may have a malignant effect on brain development in infants with TSC has stimulated the search for ways to anticipate the onset of infantile spasms before they become apparent as seizures. Recent data suggesting that hormonal therapy combined with vigabatrin may stop spasms more quickly may have important benefits for patients with TSC. This information, combined with an understanding of the genetics and neurobiology of TSC, is leading to a deeper understanding of pathogenesis and possibly better therapies.

\section{Competing interests}

The authors declare that they have no competing interests.

\section{Grant information}

The author(s) declared that no grants were involved in supporting this work. 
1. Caban C, Khan N, Hasbani DM, et al:: Genetics of tuberous sclerosis complex: implications for clinical practice. Appl Clin Genet. 2016; 10: 1-8. PubMed Abstract | Publisher Full Text | Free Full Text

2. Hoeffer CA, Klann E: mTOR signaling: at the crossroads of plasticity, memory and disease. Trends Neurosci. 2010; 33(2): 67-75. PubMed Abstract | Publisher Full Text | Free Full Text

3. Switon K, Kotulska K, Janusz-Kaminska A, et al.: Molecular neurobiology of mTOR. Neuroscience. 2017; 341: 112-53.

PubMed Abstract | Publisher Full Text

4. F Crino PB: The mTOR signalling cascade: paving new roads to cure neurological disease. Nat Rev Neurol. 2016; 12(7): 379-92. PubMed Abstract | Publisher Full Text | F1000 Recommendation

5. Northrup H, Krueger DA, International Tuberous Sclerosis Complex Consensus Group: Tuberous sclerosis complex diagnostic criteria update: recommendations of the 2012 International Tuberous Sclerosis Complex Consensus Conference. Pediatr Neurol. 2013; 49(4): 243-54. PubMed Abstract | Publisher Full Text | Free Full Text

6. Cross $\mathrm{JH}$ : Neurocutaneous syndromes and epilepsy-issues in diagnosis and management. Epilepsia. 2005; 46 Suppl 10: 17-23. PubMed Abstract | Publisher Full Text

7. Curatolo $\mathrm{P}$, Bombardieri R, Verdecchia $\mathrm{M}$, et al:: Intractable seizures in tuberous sclerosis complex: from molecular pathogenesis to the rationale for treatment. J Child Neurol. 2005; 20(4): 318-25.

PubMed Abstract | Publisher Full Text

8. F Riikonen R, Simell O: Tuberous sclerosis and infantile spasms. Dev Med Child Neurol. 1990; 32(3): 203-9.

PubMed Abstract | Publisher Full Text | F1000 Recommendation

9. Shepherd CW, Stephenson JB: Seizures and intellectual disability associated with tuberous sclerosis complex in the west of Scotland. Dev Med Child Neurol. 1992; 34(9): 766-74.

PubMed Abstract | Publisher Full Text

10. Chu-Shore CJ, Major $\mathrm{P}, \mathrm{Camposano} \mathrm{S}$, et al.: The natural history of epilepsy in tuberous sclerosis complex. Epilepsia. 2010; 51(7): 1236-41. PubMed Abstract | Publisher Full Text | Free Full Text

11. F Dombkowski AA, Batista CE, Cukovic D, et al:: Cortical Tubers: Windows into Dysregulation of Epilepsy Risk and Synaptic Signaling Genes by MicroRNAs. Cereb Cortex. 2016; 26(3): 1059-71.

PubMed Abstract | Publisher Full Text | Free Full Text | F1000 Recommendation

12. Hunt A: Development, behaviour and seizures in $\mathbf{3 0 0}$ cases of tuberous sclerosis. J Intellect Disabil Res. 1993; 37(Pt 1): 41-51.

PubMed Abstract | Publisher Full Text

13. Joinson C, O'Callaghan FJ, Osborne JP, et al.: Learning disability and epilepsy in an epidemiological sample of individuals with tuberous sclerosis complex. Psychol Med. 2003; 33(2): 335-44.

PubMed Abstract | Publisher Full Text

14. F Jansen FE, Vincken KL, Algra A, et al.: Cognitive impairment in tuberous sclerosis complex is a multifactorial condition. Neurology. 2008; 70(12): 916-23.

PubMed Abstract | Publisher Full Text | F1000 Recommendation

15. Kaczorowska M, Jurkiewicz E, Domanska-Pakiela D, et al.: Cerebral tuber count and its impact on mental outcome of patients with tuberous sclerosis complex. Epilepsia. 2011; 52(1): 22-7. PubMed Abstract | Publisher Full Tex

16. F Bolton PF, Clifford M, Tye $\mathrm{C}$, et al.: Intellectual abilities in tuberous sclerosis complex: risk factors and correlates from the Tuberous Sclerosis 2000 Study. Psychol Med. 2015; 45(11): 2321-31. PubMed Abstract | Publisher Full Text | F1000 Recommendation

17. F Wong HT, McCartney DL, Lewis JC, et al:: Intellectual ability in tuberous sclerosis complex correlates with predicted effects of mutations on TSC1 and TSC2 proteins. J Med Genet. 2015; 52(12): 815-22. PubMed Abstract | Publisher Full Text | F1000 Recommendation

18. F Overwater IE, Verhaar BJ, Lingsma HF, et al.: Interdependence of clinical factors predicting cognition in children with tuberous sclerosis complex. J Neurol. 2017; 264(1): 161-7.

PubMed Abstract | Publisher Full Text | Free Full Text | F1000 Recommendation

19. Gipson TT, Poretti A, Thomas EA, et al.: Autism Phenotypes in Tuberous Sclerosis Complex: Diagnostic and Treatment Considerations. J Child Neurol. 2015; 30(14): 1871-6.

PubMed Abstract | Publisher Full Text

20. F Vignoli A, La Briola F, Peron A, et al:: Autism spectrum disorder in tuberous sclerosis complex: searching for risk markers. Orphanet J Rare Dis. 2015; 10: 154.

PubMed Abstract | Publisher Full Text | Free Full Text | F1000 Recommendation

21. Jeste SS, Varcin KJ, Hellemann GS, et al:: Symptom profiles of autism spectrum disorder in tuberous sclerosis complex. Neurology. 2016; 87(8): 766-72. PubMed Abstract | Publisher Full Text | Free Full Text

22. Hampson DR, Blatt GJ: Autism spectrum disorders and neuropathology of the cerebellum. Front Neurosci. 2015; 9: 420

PubMled Abstract | Publisher Full Text | Free Full Text

23. Gillberg IC, Gillberg C, Ahlsen G: Autistic behaviour and attention deficits in tuberous sclerosis: a population-based study. Dev Med Child Neurol. 1994; 36(1): 50-6.

PubMed Abstract | Publisher Full Text

24. Hunt A, Shepherd C: A prevalence study of autism in tuberous sclerosis. J Autism Dev Disord. 1993; 23(2): 323-39.

PubMed Abstract | Publisher Full Text

25. Jambaqué I, Cusmai R, Curatolo P, et al.: Neuropsychological aspects of tuberous sclerosis in relation to epilepsy and MRI findings. Dev Med Child Neurol. 1991; 33(8): 698-705.

PubMed Abstract | Publisher Full Text

26. Smalley SL, Tanguay PE, Smith M, et al:: Autism and tuberous sclerosis. J Autism Dev Disord. 1992; 22(3): 339-55.

PubMed Abstract | Publisher Full Text

27. Baker P, Piven J, Sato Y: Autism and tuberous sclerosis complex: prevalence and clinical features. J Autism Dev Disord. 1998; 28(4): 279-85. PubMed Abstract | Publisher Full Text

28. Gutierrez GC, Smalley SL, Tanguay PE: Autism in tuberous sclerosis complex. J Autism Dev Disord. 1998; 28(2): 97-103. PubMed Abstract | Publisher Full Text

29. Jeste $\mathrm{SS}$, Sahin $\mathrm{M}$, Bolton $\mathrm{P}$, et al.: Characterization of autism in young children with tuberous sclerosis complex. J Child Neurol. 2008; 23(5): 520-5. PubMed Abstract | Publisher Full Text

30. Calderón González R, Treviño Welsh J, Calderón Sepúlveda A: [Autism in tuberous sclerosis]. Gac Med Mex. 1994; 130(5): 374-379. PubMed Abstract

31. Numis AL, Major P, Montenegro MA, et al.: Identification of risk factors for autism spectrum disorders in tuberous sclerosis complex. Neurology. 2011 76(11): 981-7.

PubMed Abstract | Publisher Full Text | Free Full Text

32. Bolton PF, Griffiths PD: Association of tuberous sclerosis of temporal lobes with autism and atypical autism. Lancet. 1997; 349(9049): 392-5. PubMed Abstract | Publisher Full Text

33. Granader YE, Bender HA, Zemon V, et al:: The clinical utility of the Social Responsiveness Scale and Social Communication Questionnaire in tuberous sclerosis complex. Epilepsy Behav. 2010; 18(3): 262-6. PubMed Abstract | Publisher Full Text

34. $\mathrm{F}$ de Vries PJ, Whittemore VH, Leclezio L, et al:: Tuberous sclerosis associated neuropsychiatric disorders (TAND) and the TAND Checklist. Pediatr Neurol. 2015; 52(1): 25-35

PubMed Abstract | Publisher Full Text | Free Full Text | F1000 Recommendation

35. Franz DN: Everolimus: an mTOR inhibitor for the treatment of tuberous sclerosis. Expert Rev Anticancer Ther. 2011; 11(8): 1181-92. PubMed Abstract | Publisher Full Text

36. Curran MP: Everolimus: in patients with subependymal giant cell astrocytoma associated with tuberous sclerosis complex. Paediatr Drugs. 2012; 14(1): $51-60$.

PubMed Abstract | Publisher Full Text

37. F Bissler JJ, Kingswood JC, Radzikowska E, et al: Everolimus for angiomyolipoma associated with tuberous sclerosis complex or sporadic lymphangioleiomyomatosis (EXIST-2): a multicentre, randomised, doubleblind, placebo-controlled trial. Lancet. 2013; 381(9869): 817-24. PubMed Abstract | Publisher Full Text | F1000 Recommendation

38. F McCormack FX, Inoue $\mathrm{Y}$, Moss J, et al:: Efficacy and safety of sirolimus in ymphangioleiomyomatosis. N Engl J Med. 2011; 364(17): 1595-606. PubMed Abstract | Publisher Full Text | Free Full Text | F1000 Recommendation

39. F Talos DM, Sun $\mathrm{H}$, Kosaras $\mathrm{B}$, et al:: Altered inhibition in tuberous sclerosis and type Ilb cortical dysplasia. Ann Neurol. 2012; 71(4): 539-51. PubMed Abstract | Publisher Full Text | Free Full Text | F1000 Recommendation

40. F Zhang B, McDaniel SS, Rensing NR, et al:: Vigabatrin inhibits seizures and mTOR pathway activation in a mouse model of tuberous sclerosis complex. PLoS One. 2013; 8(2): e57445.

PubMed Abstract | Publisher Full Text | Free Full Text | F1000 Recommendation

41. F Vigevano F, Cilio MR: Vigabatrin versus ACTH as first-line treatment for infantile spasms: a randomized, prospective study. Epilepsia. 1997; 38(12): $1270-4$.

PubMed Abstract | Publisher Full Text | F1000 Recommendation

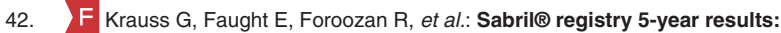
Characteristics of adult patients treated with vigabatrin. Epilepsy Behav. 2016 56: $15-9$.

PubMed Abstract | Publisher Full Text | F1000 Recommendation

43. F Wheless JW, Clarke DF, Arzimanoglou A, et al.: Treatment of pediatric epilepsy: European expert opinion, 2007. Epileptic Disord. 2007; 9(4): 353-412. PubMed Abstract | F1000 Recommendation

44. F Krueger DA, Wilfong AA, Mays M, et al.: Long-term treatment of epilepsy 
with everolimus in tuberous sclerosis. Neurology. 2016; 87(23): 2408-15 PubMed Abstract | Publisher Full Text | Free Full Text | F1000 Recommendation

45. F Samueli S, Abraham K, Dressler A, et al.: Efficacy and safety of Everolimus in children with TSC - associated epilepsy - Pilot data from an open singlecenter prospective study. Orphanet J Rare Dis. 2016; 11(1): 145. PubMed Abstract | Publisher Full Text | Free Full Text | F1000 Recommendation

46. French JA, Lawson JA, Yapici Z, et al.: Adjunctive everolimus therapy for treatment-resistant focal-onset seizures associated with tuberous sclerosis (EXIST-3): a phase 3, randomised, double-blind, placebo-controlled study. Lancet. 2016; 388(10056): 2153-63.

PubMed Abstract | Publisher Full Text

47. de Vries PJ, Hunt A, Bolton PF: The psychopathologies of children and adolescents with tuberous sclerosis complex (TSC): a postal survey of UK families. Eur Child Adolesc Psychiatry. 2007; 16(1): 16-24. PubMed Abstract | Publisher Full Text

48. Curatolo P, Moavero R, de Vries PJ: Neurological and neuropsychiatric aspects of tuberous sclerosis complex. Lancet Neurol. 2015; 14(7): 733-45. PubMed Abstract | Publisher Full Text

49. Curatolo P, Napolioni V, Moavero R: Autism spectrum disorders in tuberous sclerosis: pathogenetic pathways and implications for treatment. J Child Neurol. 2010; 25(7): 873-80. PubMed Abstract | Publisher Full Text

50. $\quad F$ Eden KE, de Vries PJ, Moss J, et al:: Self-injury and aggression in tuberous sclerosis complex: cross syndrome comparison and associated risk markers. J Neurodev Disord. 2014; 6(1): 10.

PubMed Abstract | Publisher Full Text | Free Full Text | F1000 Recommendation

51. Bolton PF, Park RJ, Higgins JN, et al:: Neuro-epileptic determinants of autism spectrum disorders in tuberous sclerosis complex. Brain. 2002; 125(Pt 6): 1247-55.

PubMed Abstract | Publisher Full Text

52. Lewis JC, Thomas HV, Murphy KC, et al: Genotype and psychological phenotype in tuberous sclerosis. J Med Genet. 2004; 41(3): 203-7. PubMed Abstract | Publisher Full Text | Free Full Text

53. Raznahan A, Joinson C, O'Callaghan F, et al.: Psychopathology in tuberous sclerosis: an overview and findings in a population-based sample of adults with tuberous sclerosis. J Intellect Disabil Res. 2006; 50(Pt 8): 561-9. PubMed Abstract | Publisher Full Text

54. Muzykewicz DA, Newberry P, Danforth N, et al:: Psychiatric comorbid conditions in a clinic population of 241 patients with tuberous sclerosis complex. Epilepsy Behav. 2007; 11(4): 506-13.

PubMed Abstract | Publisher Full Text

55. Ridler K, Suckling J, Higgins NJ, et al.: Neuroanatomical correlates of memory deficits in tuberous sclerosis complex. Cereb Cortex. 2007; 17(2): 261-71. PubMed Abstract | Publisher Full Text

56. F de Vries PJ, Gardiner J, Bolton PF: Neuropsychological attention deficits in tuberous sclerosis complex (TSC). Am J Med Genet A. 2009; 149A(3): 387-95.

PubMed Abstract | Publisher Full Text | F1000 Recommendation

57. Whittemore $\mathrm{VH}$, Lewis $\mathrm{J}$ : Impact of TSC on the family and genetic counseling issues. In: Kwiatkowski DJ, Whittemore VH, Thiele EA, eds. Tuberous Sclerosis Complex: Genes, Clinical Features and Therapeutics. Weinheim, Germany: Wiley-Blackwell, 2010; 387-396.

Publisher Full Text

58. F Davies DM, de Vries PJ, Johnson SR, et al.: Sirolimus therapy for angiomyolipoma in tuberous sclerosis and sporadic lymphangioleiomyomatosis: a phase 2 trial. Clin Cancer Res. 2011; 17(12): 4071-81.

PubMed Abstract | Publisher Full Text | F1000 Recommendation

59. F Capal JK, Franz DN: Profile of everolimus in the treatment of tuberous sclerosis complex: an evidence-based review of its place in therapy. Neuropsychiatr Dis Treat. 2016; 12: 2165-72.

PubMed Abstract | Publisher Full Text | Free Full Text | F1000 Recommendation

60. Gipson TT, Jennett H, Wachtel L, et al.: Everolimus and intensive behavioral therapy in an adolescent with tuberous sclerosis complex and severe behavior. Epilepsy Behav Case Rep. 2013; 1: 122-5. PubMed Abstract | Publisher Full Text | Free Full Text

61. Jóźwiak S, Kotulska K, Domańska-Pakieła D, et al.: Antiepileptic treatment before the onset of seizures reduces epilepsy severity and risk of mental retardation in infants with tuberous sclerosis complex. Eur J Paediatr Neurol. 2011; 15(5): 424-31.

PubMed Abstract | Publisher Full Text

62. Józwiak S, Domańska-Pakieła D, Kotulska K, et al:: Treatment before seizures: new indications for antiepileptic therapy in children with tuberous sclerosis complex. Epilepsia. 2007; 48(8): 1632; author reply 1632-4. PubMed Abstract | Publisher Full Text

63. F Wu JY, Peters JM, Goyal M, et al:: Clinical Electroencephalographic Biomarker for Impending Epilepsy in Asymptomatic Tuberous Sclerosis Complex Infants. Pediatr Neurol. 2016; 54: 29-34. PubMed Abstract | Publisher Full Text | Free Full Text | F1000 Recommendation

64. F Humphrey A, MacLean C, Ploubidis GB, et al.: Intellectual development before and after the onset of infantile spasms: a controlled prospectiv longitudinal study in tuberous sclerosis. Epilepsia. 2014; 55(1): 108-16. PubMed Abstract | Publisher Full Text | F1000 Recommendation

65. O' Callaghan FJ, Edwards SW, Alber FD, et al.: Safety and effectiveness of hormonal treatment versus hormonal treatment with vigabatrin for infantile spasms (ICISS): a randomised, multicentre, open-label trial. Lancet Neurol. 2017; 16(1): 33-42.

PubMed Abstract | Publisher Full Text

66. F Wilmshurst JM, Ibekwe RC, O'Callaghan FJ: Epileptic spasms - $\mathbf{1 7 5}$ years on Trying to teach an old dog new tricks. Seizure. 2017; 44: 81-6.

PubMed Abstract | Publisher Full Text | F1000 Recommendation 


\section{Open Peer Review}

\section{Current Peer Review Status:}

\section{Editorial Note on the Review Process}

Faculty Reviews are review articles written by the prestigious Members of Faculty Opinions. The articles are commissioned and peer reviewed before publication to ensure that the final, published version is comprehensive and accessible. The reviewers who approved the final version are listed with their names and affiliations.

\section{The reviewers who approved this article are:}

\section{Version 1}

\section{Mustafa Sahin}

Department of Neurology, F.M. Kirby Center for Neurobiology, Boston Children's Hospital, Harvard Medical School, Boston, MA, USA

Competing Interests: Mustafa Sahin has received research funding from Roche, Novartis, Pfizer and LAM Therapeutics. He has also served as a consultant for Roche and has been on the Scientific Advisory Board for SAGE Therapeutics.

\section{Peter Crino}

Department of Neurology, University of Maryland School of Medicine, Baltimore, Maryland, USA

Competing Interests: No competing interests were disclosed.

\section{Paolo Curatolo}

Child Neurology and Psychiatry Unit, Systems Medicine Department, Tor Vergata University of Rome, Rome, Italy

Competing Interests: No competing interests were disclosed. 
The benefits of publishing with F1000Research:

- Your article is published within days, with no editorial bias

- You can publish traditional articles, null/negative results, case reports, data notes and more

- The peer review process is transparent and collaborative

- Your article is indexed in PubMed after passing peer review

- Dedicated customer support at every stage

For pre-submission enquiries, contact research@f1000.com 